\title{
WES HILL
}

\section{Hipster Aesthetics: Creatives with no alternative}

\begin{abstract}
What is a hipster, and why has this cultural trope become so resonant of a particular mode of artistic and connoisseurial expression in recent times? Evolving from its beatnik origins, the stereotypical hipster today is likely to be a globally aware "creative" who nonetheless fails in their endeavour to be an exemplar of progressive cultural taste in an era when cultural value is heavily politicised. Today, artist memes and hipster memes are almost interchangeable, associated with people who are desperate to be fashionably distinctive, culturally literate or as having discovered some obscure cultural phenomenon before anyone else. But how did we arrive at this situation where elitist and generically "arty" connotations are perceived in so many cultural forms? This article will attempt to provide an historical context to the rise of the contemporary, post-1990s, hipster, who emerged out of the creative and entrepreneurial ideologies of the digital age - a time when artistic creations lose their alternative credence in the markets of the creative industries. Towards the end of the article "hipster hate" will be examined in relation to postcritical practice, in which the critical, exclusive, and in-the-know stances of cultural connoisseurs are thought to be in conflict with pluralist ideology.
\end{abstract}

\section{Hipster Aesthetics: Creatives with no alternative}

Although the hipster trope is immediately recognisable, it has been allied with a remarkable diversity of styles, objects and activities over the last two decades, warranting definition more in terms of the attempt to promote counter-mainstream sensibilities than pertaining to a specific aesthetic as such. People rarely identify themselves as hipsters, and the term itself has long been contested, a generic signifier for those who embody both a generic brand of artiness and a pluralist cultural ideal. While more specific terms such as "twee", "health goth", "normcore", "lumbersexual" and "yuccies" (young urban creative yuppies) describe a range of hipster subgroups, the currency of the term "hipster" has hardly diminished, remaining relevant, perhaps, by virtue of its totalizing sensibility a shorthand term for people we can easily identify but also find difficult to define without implicating our own tastes. Fundamental to the hipster trope then is the very perception of what a hipster is, as if entailing the processes by which displays of progressive outlooks are denounced in the name of even more progressive outlooks. But why has the hipster become such a dominant marker of twenty-first-century life in the first place? Where did it come from and where is it going?

Writing for the New York Times in 2013, Steven Kurutz has observed that there no longer appears to be any clothes or hobbies that one could wear or participate in to avoid the hipster label, asking: 'has there ever been a subculture this broadly defined?' ${ }^{1}$ He writes:

\footnotetext{
${ }^{1}$ Kurutz, 2013: http://www.nytimes.com/2013/09/15/opinion/sunday/caught-in-the-hipster-trap.html? re $\mathrm{r}=$; 1 October, 2014.
} 
Even the basic building blocks of a wardrobe have been hipsterfied. Jeans, especially slim-cut denim, are a hipster essential. So are white T-shirts, leather jackets and hooded sweatshirts. I could wear suits. But they would have to be boxy styles from Men's Wearhouse, because anything slim or tailored is the province of high-fashion hipsters ... Want to take up a pastime? Cooking, farming, knitting, woodcraft, photography, beekeeping and bicycling are considered hipster hobbies. Hipsters love their iPhones, yet swoon over antiquated technology like typewriters and record players, so Luddites can't even stand apart. ${ }^{2}$

Michelle Persad's clickbait article for The Huffington Post similarly noted the diversity of hipster identifiers but focussed specifically on female hipsters, nominating an array of styles that have acquired the hipster taint, such as Fjallraven backpacks, pastel-coloured hair, oversized glasses, suspenders, denim cut-off shorts, bright beanies and muscle shirts with low arm holes. ${ }^{3}$ As both of these populist accounts suggest, hipster style is fundamentally permeable, driven more by the desire for distinctiveness regardless of what form this takes.

While attempts to present artful fashions and obscure cultural interests are the dominant markers of the hipster trope, ethical stylization has increasingly become an essential hipster attribute, where one's ethical stances take on the appearance of affected public performances. While interested in macro-political issues such as global warming or capitalist exploitation, the hipster is more likely to focus on localised displays of ethics, with emphasis on self-fashioning and lifestyle. Here, the micro-politics of wearing recycled clothes, drinking fair-trade coffee, using eco-friendly products, eating free-range eggs and supporting activist causes on Facebook supplant more ambitious attempts at political transformation.

The Internet's unbridled distribution of things has helped to shift the associations of the hipster towards the image of the trans-cultural "creative" of the twenty-first-century, whose failed attempts to be distinctive - to defy easy, mainstream categorisation - might see them embracing local, cosmopolitan, trashy, and sophisticated culture alike. It was the global spread of capitalism, however, that triggered the expansion of this stereotype beyond its American origins. In recent scholarship on contemporary China's youth subcultures, the hipster equivalent is referred to as “wenyi qingnian” (文艺青年), which literally means "artistic and cultural youth". ${ }^{4}$ Shan Huang describes this emergent subculture as consisting mostly of urban college students from middle-class families that emerged in post-socialist China in the 1990s. "Wenyi" youth engage in a range of alternative activities but are typically associated with independent music and culture magazines. They are committed to 'taste cultivation' and to developing detailed knowledge of "cultural products that differ from those that are popular or "mainstream",

\footnotetext{
${ }^{2}$ Kurutz, 2013.

${ }^{3}$ Persad, 2014: http://www.huffingtonpost.com.au/entry/hipsterclothing n 5589392.html?section=australia; 2 February, 2016.

${ }^{4}$ Huang, 2014, p. 42.
} 
however, Huang notes that such connoisseurship largely serves to optimize aesthetic pleasure rather than to aid knowledge of the socio-political issues underpinning their cultural preferences. ${ }^{5}$

As Arjun Appadurai has claimed, neither centrality nor peripherality exists in the context of cultural globalisation. Rather, the flow of signs and their associated values comprise a 'complex, overlapping, disjunctive order' in which 'the ideas and images produced by mass media often are only partial guides to the goods and experiences that deterritorialized populations transfer to one another. ${ }^{6}$ Cultural value is decentralised in the global spread of capitalism, hence the re-emergence of the maligned figure of the hipster, whose discerning stance intimates ideals of progressive cultural taste. For Rob Horning, the hipster is the embodiment of postmodernism as a spent force, symbolising the moment when 'pastiche and irony exhaust themselves as aesthetics. ${ }^{7}$ Indeed, the very notion of a cultural elite - a creative connoisseur - is at odds with the radical pluralism and contested ground of culture today. In this sense, the hipster serves as a complex model around which discussions of identity and authenticity circulate, and where local cultural sensibilities coincide with, or attempt to resist, international trends.

\section{Hipster Origins}

Of course, "hipster" first emerged in the 1930s from the slang word "hep", which, in the American jazz world, meant cool or in-the-know. "Hep cat" was first defined by the jazz musician Cab Calloway in his 1939 Hepster's Dictionary as 'a guy who knows all the answers, understands jive. ${ }^{, 8}$ When "hipster" entered into the lexicon of the 1940s it referred to male African-American jazz aficionados whose bebop style, drug-taking, fashion sense, and dialect (their "jive") aided the establishment of a creative elite, where the performer was seen more as an avant-gardist than an entertainer. As opposed to the standard tuxedos that swing musicians wore, bebop hipsters wore wing-collar shirts, drape-shape suits, berets, horn-rimmed glasses and other outlandish accessories, aiming to connote distinctiveness and style.

In 1948, Anatole Broyard, an author of African-American ancestry, defined the hipster as 'the illegitimate son of the Lost Generation', portraying a romantic cultural figure who was the embodiment of transgression. ${ }^{9}$ Hipsters attempted to bypass the mainstream system that might have afforded them little social status, locating themselves, according to Broyard, in the ambiguous yet purposeful space of 'somewhereness'. ${ }^{10}$ Towards the end of his article Broyard reflected on the co-option of this countercultural attitude, claiming that 'the hipster - once an unregenerate Individualist, an underground poet, a guerrilla - had become a pretentious poet laureate. ${ }^{11}$ It is here - in 1948 - that the hipster

\footnotetext{
${ }^{5}$ Huang, 2014, pp. 47-55.

${ }^{6}$ Appadurai, 1990, p. 303.

${ }^{7}$ Horning, 2009: http://www.popmatters.com/post/the-death-of-the-hipster-panel/; 30 September, 2014.

${ }^{8}$ Calloway, 1976, p. 255.

${ }^{9}$ Broyard, 1948, p. 721.

${ }^{10}$ Broyad, 1948, p. 721.

${ }^{11}$ Broyard, 1948, p. 725.
} 
trope was first defined as counter-mainstream and yet also prone to mainstream exploitation, even before its appropriation by white beatnik culture.

Following Allen Ginsberg's more earnest portrayal of 'angelheaded hipsters' in his 1955 poem Howl, ${ }^{12}$ Norman Mailer's The White Negro: Superficial Reflections on the Hipster (1957) described the hipster as a new type of white, male, avant-garde figure; a composite of the 'negro', the 'bohemian' and the 'juvenile delinquent'. ${ }^{13}$ Mailer's analysis rested problematically on an idea of African-Americans as subaltern beings of cool knowledge, exoticised passion and violence. Addressing the post-war divisions between those who were 'hip' and those who were 'squares', he argued that the period after World War Two in America was an age of intense fear, and white hipsters possessed the courage to withdraw from the conservative mainstream, adopting the 'in-flux' and 'on-the-fringe' ${ }^{14}$ lifestyles of African Americans as markers of creative rebellion. ${ }^{15}$

Here the hipster was seen as updating the discerning poses of nineteenth-century flâneurs and dandies in light of what Mailer called the birth of the 'American existentialist'. ${ }^{16}$ This was a person who knows that 'if our collective condition is to live with instant death by atomic war ... then the only life-giving answer is to accept the terms of death, to live with death as immediate danger, to divorce oneself from society, to exist without roots, to set out on that uncharted journey into the rebellious imperatives of the self., ${ }^{17}$ Resisting the horrors of World War Two by rebelling through music and fashion, the existentialist and life-affirming tendencies of the hipster manifested in a broad range of subcultural identities throughout the 1940s and '50s, including the Zazous of France, the Schlurfs of Germany and Austria, the Zoot Suiters of America, the Teddy Boys of Britain, the Stilyagi of the Soviet Union, and the Potápki of Czechoslovakia - all a complex mixture of genuine political rebellion and stylistic posturing that reacted against the soberness of their local environments.

By the early 1960s, hipsters no longer blended into beatniks. Ned Polsky observed in 1967 that hipsters had acquired pejorative associations 'among Village beats today' ${ }^{18}$, and, in the late 1970s, the British cultural theorist Dick Hebdige described them as part of a broader practice of abstracting elements of black culture in order to enact a 'freedomin-bondage' from the expectations of middle and upper class life. ${ }^{19}$ Against the more authentic beatnik, the hipster was a borderline mainstream figure, someone who at first sets out to represent a kind of hip resistance yet is seemingly unconcerned about their

\footnotetext{
${ }^{12}$ Ginsberg, 1959, p. 3.

${ }^{13}$ Mailer, 1957, p. 282.

${ }^{14}$ Mailer, 1957, p. 285. p. 180.

${ }^{16}$ Mailer, 1957, p. 276.

${ }^{17}$ Mailer, 1957, p. 276.

${ }^{18}$ Polsky, 1967, p. 151.

${ }^{19}$ Hebdige, 1979, p. 48.
}

${ }^{15}$ For the emergent Beats, black culture contrasted with the sedentary lifestyles expected of white middleclass culture, as indicated by On the Road (1957), the bible of the Beat Generation in which Jack Kerouac writes: 'At lilac evening I walked with every muscle aching amongst the lights of 27th and Welton in the Denver coloured section wishing I were a Negro, feeling that the best the white world has offered me was not enough ecstasy for me, not enough life, joy, kicks, darkness, music, not enough night.' Kerouac, 1976, 
own participation in the co-option of black culture, and the commodification of their cool, white-boy stance. ${ }^{20}$

Although the term was on the wane from the mid-1960s, the stereotype of the affected figure of the hipster hung over a diverse range of subcultures and street-styles in the postmodern period, such as the punks, new romantics, goths and casuals. While this cross-section of subcultures obviously has diverse and highly politicised histories, the question of authenticity was central to their development in an age of mass media and cross-national marketing. In the words of Hebdige: 'the meaning of subculture is, then, always in dispute, and style is the area in which the opposing definitions clash with most dramatic force. ${ }^{21}$ This amounts to a tension at the heart of subcultural aesthetics, between those who see their aesthetic sensibility as 'a crime against the natural order' and those who come to the same scene without such radical investment. ${ }^{22}$ The hipster unwittingly stimulates tension between subcultural and mainstream identity, revealing the difficulty of identifying political, critical or ethical authenticity through aesthetic displays alone.

\section{The Creative Age}

In August 1994, the front cover of Time magazine had the headline 'Everybody's Hip (And That's Not Cool)', accompanied by a version of Grant Wood's American Gothic (1930) that parodied then-current trends for roller blades and male earrings. In the feature article, If Everyone is Hip ... Is Anyone Hip?, Richard Lacayo lamented the rise of hipness at a time when "independent and "alternative" were specific genres in music and film, Kurt Cobain had just committed suicide, heroin chic and grunge were mainstream fashion styles and the twenty-fifth anniversary of Woodstock had just been staged. Lacayo argued that clever marketing had made hipness 'a special condition almost everyone seems to aspire to'. ${ }^{23}$ He writes:

At a time when the pavements are worn thin by Doc Martens, when every open door admits a file of backward baseball caps and soul patches, when jocks sell attitude and all of rock is supposed to be alternative - hipness is bigger than General Motors. ... When the ironies of Jerry Seinfeld and David Letterman occupy the best time slots on television, and even the President's daughter is named after a Joni Mitchell song, hipness is giving off an arthritic creak. It's true that nothing is more difficult to pin down than the sensibility of an era, and nothing harder to trace with certainty than its rise and fall. But in a society so adept at distributing the very latest thing and bestowing an edge upon the most unremarkable consumer fodder Miles Davis wore khakis! - it's impossible not to recognize that hip

\footnotetext{
${ }^{20}$ For Hebdige, hipsters aspired to the finer things in life but ultimately they were lower-class dandies, more strategic than the beats, who 'expressed a magical relation to poverty'. Hebdige, 1979, p. 48.

${ }^{21}$ Hebdige, 1979 , p. 3.

${ }^{22}$ Hebdige, 1979, p. 3.

${ }^{23}$ Lacayo, 1994, p. 49.
} 
is losing its force, muddling its message, becoming just another sales pitch. $^{24}$

Lacayo's article presciently captures something of the rise of hip consumerism during this period, where 'alternative' in 'alternative culture' has increasingly shallow connotations; less as a substitute for mainstream taste than a specific market sensibility. The phrase "hipster doofus" was first used in a Seinfeld (1989 -1998) episode in 1993, anticipating the re-entry of "hipster" into the popular lexicon a few years later. Kramer, played by Michael Richards, can be seen in retrospect as a caricatured version of the twenty-first-century hipster. With his determined individualism, propensity towards novel schemes, niche market entrepreneurship and vintage clothes, Kramer is essentially a selfmade creative whose idiosyncratic identity is fashioned to be out of synch with mainstream taste but also not diametrically opposed to it either.

It is no coincidence that the mining of alternative markets in many capitalist cultures around the world in the 1990s coincided with the widespread restructuring of arts funding and education, following changes forged by creative industries policies. Creative industries discourse helped to turn "creativity" into a buzzword, and instigated shifts in arts infrastructure not only in America, the UK and Australia, but also in countries as diverse as Brazil, Rwanda, India and South Korea. First introduced in Australia by Paul Keating's Labour government in the early 1990s under the rubric "creative nation", the creative industries became central to UK Prime Minister Tony Blair's incoming New Labour administration of 1997, who established the Creative Industries Unit and Taskforce. The Blair government stimulated discussion around the world about the need for governments to reconceive of cultural production in relation to economic growth. The initial aim of creative industries policy was to shift a perception of the arts from its association with government subsidisation to its place at the cutting edge of the bourgeoning information and knowledge economies, spurred by the transformative effects of digital technology.

Richard Florida's "creative class" concept arrived at the end of the dot-com boom in 2002 but it has since become aligned with creative industries policy-making at large. ${ }^{25} \mathrm{In}$ an attempt to define what he saw as the 'emerging Creative Age', Florida claimed that creativity was 'the defining feature of economic life', and he proceeded to lay out a formula for economic growth by focussing on the construction of creative centres and cities. ${ }^{26} \mathrm{He}$ thought that members of the creative class were to be found in a variety of professions, not only within the creative industries but also in the public sector, especially in the areas of technology, science and higher education. ${ }^{27}$

\footnotetext{
${ }^{24}$ Lacayo, 1994, p. 48.

${ }^{25}$ Florida, 2002, p. 37.

${ }^{26}$ Florida, 2002, p. 21.

${ }^{27}$ Apple's 'think different' ad campaign, launched in 1997, is an iconic example of this ambition at the time to apply artistic ideals of creativity and counter-mainstream thought to non-arts professions, especially in the computing industries.
} 
Whereas in the industrial age workers flocked towards factories, Florida thought that in the digital age companies looked to establish themselves in liberal, artistically rich, diverse and tolerant environments, in the hope of attracting cutting-edge pioneers. Florida's theory held that cultural life is of vital importance to economic growth, and he depicted a model of early-twenty-first-century life in which big business and creative expression worked together. He used the creative class concept to showcase how creative communities can re-brand city areas and foster new local economies without much government intervention. It is in this sense that the twenty-first-century hipster became aligned with urban gentrification, characterised by arts graduates who establish local collectives and promote alternative lifestyles, inevitably transforming their surrounds. By the early-2000s, hipster gentrification expanded beyond the overlooked corners of urban centres such as Williamsburg in New York, Kreuzberg in Berlin, Shoreditch in London and Shibuya in Tokyo to be identifiable in most parts of the developed world, in most cases spanning genders and ethnicities. ${ }^{28}$

From our current perspective, the creative age that gave rise to the twenty-first-century hipster is a prime example of neo-liberalist ideology. We could add to this abbreviated historical narrative Ronald Reagan's trickledown economics in the 1980s; Margaret Thatcher's privatisation and union busting policies; Bill Clinton's welfare reform and abolition of the Glass-Steagall Act that separated investment and commercial banking activities; and the Hawke-Keating government's financial market deregulations, industrial relations reform, tariff reductions and floating of the Australian dollar. For David Harvey, neoliberalism is rooted in such policies, defining it as a 'theory of political economic practices that proposes that human well-being can best be advanced by liberating individual entrepreneurial freedoms and skills within an institutional framework characterized by strong private property rights, free markets, and free trade., ${ }^{29}$

Although it is often used as a blanket term for critics of global capitalism, fiscal austerity or the privatisation of publicly owned assets, on a basic level neoliberalism is the belief that maximizing the reach and occurrence of market transactions will lead to social benefits, essentially bringing all human action into the sphere of the market. In Michel Foucault's lectures on biopolitics in the late 1970s, he presciently perceived the neoliberal ideal to be a new way in which people are made into subjects. Whereas in its classical liberalist form homo oeconomicus - the principle that people try to maximize their gains - represented the basis of governmental action, Foucault sees neoliberalism as a form of governance in which people effectively govern themselves. ${ }^{30}$

\footnotetext{
${ }^{28}$ In 2013 Florida admitted to some flaws in his earlier argument about the transformative effect of the creative class. In an article titled More Losers Than Winners in America's New Economic Geography he rather meekly lamented that the benefits of appealing to the creative class 'flow disproportionately to more highly-skilled knowledge, professional and creative workers', because the wage increases that blue-collar and lower-skilled workers see 'disappear when their higher housing costs are taken into account. ... On close inspection, talent clustering provides little in the way of trickle-down benefits.' Florida, 2013: http://www.citylab.com/work/2013/01/more-losers-winners-americas-new-economic-geography/4465/; 19 September, 2014.

${ }^{29}$ Harvey, 2005, p. 2.

${ }^{30}$ Foucault, 2008, p. 239.
} 
Defining neoliberalism as 'the application of the economic grid to social phenomena,' Foucault thought that in such a context workers begin to regard the self as a type of 'abilities-machine', where they are less partners in the processes of economic exchange than independent producers of 'human capital', transforming the notion of wages into the revenue earned on an investment in one's own abilities. ${ }^{31}$ Here, any activity that increases the capacity to earn income or to achieve happiness (such as work, education, marriage or migration), becomes an investment in one's self as human capital, forging a system where mobility, innovation, competition and growth are rewarded. ${ }^{32}$ For Foucault, in this neoliberal scenario: 'homo oeconomicus is an entrepreneur, an entrepreneur of himself., ${ }^{33}$ As Jason Read has argued, as a style of governmentality, neoliberalism 'would seem paradoxically to govern without governing; that is, in order to function its subjects must have a great deal of freedom to act - to choose between competing strategies. ${ }^{34}$ It is in this sense that creative freedom has become a hallmark of neoliberal governments - the freedom to fashion difference in whatever market we choose.

\section{An Art that is Alternative to What?}

In the art of the 1990s, this neoliberalist mode of the 'self-as-entrepreneur' was most visible in the Young British Artists (YBAs), whose landmark exhibition, Sensation, opened in Britain in 1997 before touring around the world. Emerging out of a recession in Britain that began in 1989, the economic downturn fostered a D.I.Y. spirit of entrepreneurialism, and compelled emerging British artists to re-build British art in a more up-to-date image, rejecting what they saw as its elitist and provincialist legacy. Artists such as Tracey Emin, Damien Hirst, Marcus Harvey, and Sarah Lucas were involved in artist-run-spaces at the start of their careers and later embraced mass media publicity and private sponsorship almost as aspects of their practices, setting their brash, visceral and conceptual visions of art within a broad cultural environment.

The YBAs became known for promoting a grungy sense of cool that was steeped in nostalgia for 1960s pop art and 1970s punk, echoing grunge fashion and the hype for Britpop bands such as Blur and Oasis at this time. Largely supported and displayed through private capital, notably that of Charles Saatchi - an advertising mogul closely associated with the Conservative Party during its years of dominance in the early 1980s many of the YBAs promoted their lifestyles in newly launched art and culture magazines, as if presenting an image of the bohemian artist in an age of global capitalism. They became seen as transgressive but also as signalling a move away from the commodity critiques of the neo-avant-garde artists of the 1980s, showing a distinct sense of ease with

\footnotetext{
${ }^{31}$ Foucault, 2008, pp. 226-229.

${ }^{32}$ In this neoliberal context, Foucault claims that inherited genetic capabilities which differ from person to person (such as gender, race or physical appearance), are perceived merely as natural limits that have the potential to be overcome through technologies, or by undertaking further 'investments' in the self, with subjects granted full responsibility for their own investment decisions. This issue of eradicating physical limitations in one's quest for capital is acknowledged by Foucault as if he is just 'engaging in a bit of science fiction', but, he continues, 'it is a kind of problematic which is currently becoming pervasive.'

Foucault, 2008, p. 227.

${ }^{33}$ Foucault, 2008, p. 226.

${ }^{34}$ Read, 2009, p. 29.
} 
the convergence of post-conceptual practice and mass entertainment. Situating their work into a large public narrative, the YBAs acted in a context where art's status as at once a luxury commodity and a trigger for public discussion was more a starting point than an end point - less a neo-avant-garde commentary than a reflection of the reality of art as a cultural industry.

For Julian Stallabrass, the business-like approach of the YBAs mirrored the changes that cultural institutions in Britain were undergoing. The 'gradual long-term withdrawal of state funding' that began in Britain in the early 1990s forced art galleries and museums 'to become increasingly run on business lines, judged primarily by the numbers who are channelled through their halls. ${ }^{35}$ For Stallabrass this situation reflected a postpostmodern period that moved from the 'divisive and atomised identity politics' of postmodernism to 'an art of pure consumer choice. ${ }^{, 36}$ Acquiring the label "Cool Britannia", the YBAs fostered an image of the contemporary art world as a forum for the expression of alternative viewpoints and subcultural style that could shock and yet still be absorbed by the market. ${ }^{37}$ By the end of the 1990s, the YBAs were as familiar to tabloid newspaper readers in Britain as they were to art-world insiders, and contemporary art was promoted by the media, and by British politicians, in terms of it emulating models of consumption on par with the fashion, popular music, television and film industries.

In a 1997 article for The New Yorker, Malcolm Gladwell argued that the search for and marketing of cool culture had become a cultural zeitgeist. The term "cool hunting" emerged in the 1990s as a market research phenomenon that aimed to discover new trends in urban subcultures for the purpose of mass marketing. Gladwell writes:

what everybody seems to want these days [...] is a window on the world of the street. Once, when fashion trends were set by the big couture houses - when cool was trickle-down - that wasn't important. But sometime in the past few decades things got turned over, and fashion became trickle-up. ${ }^{38}$

Beyond the commercial exploitation of subcultural distinctiveness, what connects the YBAs and the cool hunting phenomenon is this idea of a cultural vernacular, where everyday culture in all of its diversity, particularly street culture, becomes a site for individual, creative and non-conformist identity - what Thomas Frank named in 1997 as

\footnotetext{
35 Julian Stallabrass, 1999, p. 201

${ }^{36}$ Julian Stallabrass, 1999, p. 202

${ }^{37}$ British art historian and critic Christopher Frayling, a former rector at the Royal College of Art, claims that this period was characterised by 'a convergence of advertising and art.' He continues: 'I remember artists in the 1970s who thought their role was to put two fingers up at the establishment and deliberately produce art which was unexhibitable. They didn't want to be marketed. But these [post 1970s artists] were the children of Thatcher. There was an idea that they ought to be more hip to the real world. I was swamped. They wanted to know how to get on, how to charge commission, how to get an exhibition.' Millard, 2001, p. 53.

${ }^{38}$ Gladwell, 1997: http://www.newyorker.com/magazine/1997/03/17/the-coolhunt; accessed 2 January, 2016.
} 
the rise of the 'rebel consumer'. ${ }^{39}$ The newly launched category of "alternative sports" in the 1990s is yet another iteration of this mining of street authenticity. Like the YBAs, skateboarding, along with snowboarding, BMX riding, and base jumping, was branded in terms of D.I.Y. attitude, creativity and anti-authoritarianism. Artists such as Dash Snow, Ryan McGinley, Harmony Korine and Ed Templeton all emerged as artists in the early 2000s from backgrounds in skateboarding, adopting rebellious personas that were exploited by companies such as Vice magazine and American Apparel (founded 1994 and 1997 respectively) who aligned themselves with this once marginalised activity.

Although the YBAs' blend of subcultural aesthetics and cool advertising prefigure the misplaced hipness of the twenty-first-century hipster, it is relational aesthetics - that other well-known 1990s art movement - which more closely emulates the hipster's ethical and critical aspirations. Relational aesthetics was coined by the French curator Nicolas Bourriaud in the mid 1990s as a tendency in art practice, a critical theory and an exhibition rationale all in one, purporting to offer new models of socially conscious art that was reflective of the emergent networked sensibility of digital media and popular forms of entertainment such as video games. Bourriaud was also grappling with the very relevance of critical practice in contemporary art, in response to what Hal Foster called in 1993 the failure of 'the art-critical version of postmodernism. ${ }^{40}$ Bourriaud saw critical and aesthetic judgment as requiring a different, less content-determined approach (and revolving more around the dialogical nature of 'artistic form, ${ }^{41}$ ), in acknowledgment of how the global art context frequently provides encounters with foreign reference points and unfamiliar motivations.

Published in French at the same time as Tony Blair's New Labour government in Britain began implementing their creative industries policies, in Esthétique relationnelle Bourriaud professed sympathy for the countercultural practices of historical groups such as the Situationist International, which was led by Guy Debord. In Debord's 1967 account of the Society of the Spectacle, he argued the central role of the commodity in capitalism as analysed by Marx had been superseded by the spectacle, where social relations between people are mediated by images rather than by money. ${ }^{42}$ In consuming images in this way, people are coerced into a form of brainwashing; the spectacle obscures the direct experiences of social relations, standardises thought and causes alienation from one's own self. Bourriaud agreed, declaring that the 'social bond has been turned into a standardized artefact' where it seems that 'anything that cannot be marketed will inevitably vanish'. ${ }^{43}$ Bourriaud goes on to assert that if, in Debord's terms, the media spectacle dominates communicational and social exchanges, then 'it can only be analysed and fought through the production of new relationships between people'. ${ }^{44}$

\footnotetext{
${ }^{39}$ Frank, 1997, p. 14.

${ }^{40}$ Foster, 1993, p. 4.

${ }^{41}$ Bourriaud, 2002, p. 22.

${ }^{4}$ Debord, 1994, p. 12.

${ }^{43}$ Bourriaud, 2002, p. 9.

${ }^{44}$ Bourriaud, 2002, p. 85.
} 
Unlike Debord, Bourriaud claimed that relational artists no longer try to negate the status quo from a revolutionary position outside the dominant culture. Like the status of bartering or autarky within a capitalist context, works by artists such as Rirkrit Tiravanija, Pierre Huyghe, Vanessa Beecroft, Dominique Gonzalez-Foerster and Liam Gillick were thought to operate as interstitial social practices, proposing 'alternatives for living' that 'fit more or less harmoniously and openly into the overall system'. ${ }^{45}$ Whereas Debord considered art to be subordinate to the revolutions that were required in day-today life, Bourriaud saw the field of art in the 1990s as having opened up to art practices that can perform something similar to Debord's 'concrete situations'. ${ }^{46}$ In an era when 'any stance that is directly critical of society is futile, if based on the illusion of a marginality that is nowadays impossible, not to say regressive', ${ }^{47}$ Bourriaud acknowledged that the art world is implicated in a larger capitalist system; however, in dealing primarily with social relations, relational art suggests 'other trading possibilities than those in effect' in the capitalist system, and can therefore 'elude the capitalist economic context by being removed from the law of profit'. ${ }^{48}$ Here the actualities of social encounters are seen to resist the image-world and profit-directed relations of capitalism, triggering active rather than passive modes of viewership. ${ }^{49}$ These practices are "indirectly" critical in so far as they provide situations in which to experience 'art's capacities of resistance within the overall social arena. ${ }^{, 50}$

While there is merit in Bourriaud's endeavour, as George Baker has pointed out: 'at its most ambitious, Bourriaud's project amounts to a theory of advanced art in the era of a putatively new service economy, a context within which, it is claimed, art abandons its prior (industrial) object forms and shifts to the immaterial form of services."

Bourriaud's urbane representation of communal aesthetics and conflict-free depiction of political engagement - under the auspice of a benign arts institution - has largely condemned relational aesthetics to the same fate as the hipster, amounting to what Foster called an 'arty party', where artists and curators 'fall for the Internet rhetoric of "interactivity." 52 Today such posturing has become synonymous more with fauxhemianism than with the goals of the Situationists, representing a cleaned-up version of countercultural expression borne from utopian ideas of portfolio careers, digital entrepreneurship and the creative economy. All this in spite of the fact that Bourriaud sets his agenda away from a future (political) utopia in favour of staging 'microtopias' in the here and now. ${ }^{53}$ However, note the resemblance here between a "microtopian ethos" and the stereotype of the hipster whose ethics often find their expression in local scenarios, as an extension of alternative lifestyle.

\footnotetext{
45 Bourriaud, 2002, p. 16.

${ }^{46}$ Debord, 1994, p. 13.

${ }^{47}$ Bourriaud, 2002, p. 31.

${ }^{48}$ Bourriaud, 2002, p. 16.

${ }^{49}$ Bourriaud, 2002, p. 45.

${ }^{50}$ Bourriaud, 2002, p. 31.

${ }^{51}$ Baker, 2004, p. 50.

${ }^{52}$ Foster, 2003, p. 21.

${ }^{53}$ Bourriaud, 2002, p. 13.
} 
Despite perceiving political potential in the open-ended and collaborative nature of relational art, it was perhaps the very notoriety of Bourriaud's theory, and his high-profile artists, which ultimately led to the transformation of his ideas into markers of strategic professionalism and managerial ideology in a new era of post-critical art. The interactions offered by relational art, which were staged throughout the world, acquired a tone of radical-yet-institutionalised cool - conceptualist ephemerality that could remain firmly entrenched within a capitalist context. In an article on theanyspacewhatever exhibition at the Guggenheim Museum in 2008 (which marked the twentieth anniversary of the launch of relational art), art critic Jerry Saltz retrospectively described the movement as part of the broader transformation of art museums into 'smash-hit consumer circuses, box-office sensations of voyeurism and hipster showbiz' ${ }^{54}$ Kyle Chayka has similarly highlighted the waning relevance of relational aesthetics from a contemporary standpoint, claiming that it is 'still redolent of the 1990s that it came of age in - the beginnings of Internet culture, instant communication, and the instantaneous gain and loss of celebrity, but without the same cynicism we've developed today. 55

For Grant Kester, the soft ethical ideals associated with Bourriaud's account of relational art, and embodied by the twenty-first-century hipster, stem from a confusion of aesthetics and politics. Kester is among a host of theorists in recent years that are quick to draw attention to the conformism of much self-declared political art. ${ }^{56}$ Kester is sceptical of aesthetic thinking which he attributes not only to relational aesthetics but also to the work of fellow high-profile art writers such as Claire Bishop, whose well-known criticism of Bourriaud's theory claimed that it failed to grasp how antagonism is the defining feature of political engagement. Bishop saw Bourriaud as endorsing an ersatz political art where the quality of such encounters is never questioned because it is assumed that all relations that permit dialogue or exchange are intrinsically 'democratic and therefore good. ${ }^{57}$ Kester, on the other hand, holds that we should be sceptical of all aesthetic postures that purport to be anything but subjective. He thinks that collaborative and solution-focused models of art - in which ethical reflection is a central feature - can counter the superficial forms of social interaction that "aesthetic art" can promote, arguing that artists should overcome their own privileged status in order to create equal dialogues with viewerparticipants.

Although Bishop has similarly advocated socially-engaged practices that work against the 'neoliberal idea of community', 58 she warns against what she believes is Kester's reduction of art to moral criteria, maintaining that questions of aesthetic judgement can still be political because of art's capacity to 'disrupt the relationship among the visible, the sayable, and the thinkable without having to use the terms of a message as a vehicle. ${ }^{59}$ In short, both Kester and Bishop are interested in what constitutes effective countercultural practice yet Kester remains wary of the rhetoric surrounding the

\footnotetext{
${ }^{54}$ Saltz, 2011: http://nymag.com/arts/cultureawards/2011/museums-as-playgrounds/; 10 September, 2014.

${ }^{55}$ Chayka, 2011: http://hyperallergic.com/18426/wtf-is-relational-aesthetics/; 21 September, 2014.

${ }^{56}$ Kester, 2009, p.8.

${ }^{57}$ Bishop, 2004, p. 65.

${ }^{58}$ Bishop, 2012, p. 14.

${ }^{59}$ Bishop, 2006, p. 24.
} 
"aesthetics as textual analysis" mode of art making. Linking 'critical art writing' with 'aesthetic judgment', Kester argues that both practices promote a textual politics 'centred on a process of critical reading, or decoding' that can unwittingly serve to insulate 'the act of critique [...] from the exigencies of practice or direct action. ${ }^{60}$ What is radical about Kester's approach is that he appears to argue for a quantitative account of art, where the value of an artwork is measured more by its social impact than its stylistic innovations, or the forms through which its social commentaries are presented.

\section{Post-Critical}

These debates about the political currency of aesthetics are indicative of the animosity surrounding the creative, connoisseurial and ethically minded figure of the hipster in the twenty-first century. Where once hipsters were seen as part of a culture of white bourgeois patriarchy who claimed alienation from their familial class only to try to oneup them by displaying tastes that were considered too macho, too lower-class, or too much like an embodied Other, today the hipster represents a more general posture of cultural knowingness, routinely called out for its masking of an exclusionary politics. ${ }^{61}$

Self-declared post-critical writers such as Bruno Latour and Ronald Jones have argued, in their own unique ways, that the provisional and contingent nature of cultural value in these pluralistic times is at odds with the speculative essentialism of earlier models of critical, oppositional or countercultural practice. Instead, Jones proposes 'proactive strategies triggering entrepreneurial [...] interdisciplinary, innovative and attainable solutions to our collective challenges'. ${ }^{62}$ Here, "post-critical" stands for innovative pragmatism and community building, following the idea that cultural expressions should be directed towards the improvement of life rather than producing 'more iconoclasm to iconoclasm, ${ }^{63}$

These denunciations of critical and "knowing" aesthetics have been added to by Jacques Rancière, who criticised Bourriaud, and relational art in general, for adopting stances that seek to converge aesthetics and politics by rejecting the notion of art's autonomy. Rancière argues that it is precisely the autonomy of the aesthetic space (where cultural forms do not adhere to prescribed content, normative criteria, thematic hierarchy or preordained socio-political roles) that enables 'material and symbolic space' to be reframed, performing the same task as politics by way of reorganising accepted perceptions of reality. ${ }^{64}$ Rancière positions his account of the aesthetic regime against Bourriaud's emphasis on an art of social relations, where 'action is presented as the only answer to the evil of the image and [passive] guilt of the spectator. ${ }^{65}$ Categorised by

\footnotetext{
${ }^{60}$ Kester, 2011, p. 13.

${ }^{61}$ After the 2008 Global Financial Crisis alerted many people around the world to the pervasive social inequalities of contemporary life, the hipster trope has become central to the negative portrayal of "creative class" ideals, as seen in popular TV shows such as Girls (2012-16) Portlandia (2011-16), Bondi Hipsters (2014), 2 Broke Girls (2012-16) and Horace and Pete (2016), to name just a few.

62 Jones, 2010, p. 57.

${ }^{63}$ Latour, 2004, p. 225.

${ }^{64}$ Rancière, 2009a, p. 24.

${ }^{65}$ Rancière, 2009b, p. 87.
} 
Foster as a post-critical thinker, Rancière's work has popularised a turn against those who conceive of art and aesthetics in terms of the transferral of knowledge from the artist's mind to that of the viewer's. He disparages 'critical art' as 'a type of art that sets out to build awareness of the mechanisms of domination to turn the spectator into a conscious agent of world transformation', which portrays viewers as if they are awaiting liberation from their own illusory values in order to be shown things as they really are. ${ }^{66}$

Like the post-critical concept, the trope of the hipster is caught up in this question of how to denounce the subjective critical assumptions of others while acknowledging the subjective critical assumptions that underpin one's own position. It is a sensibility that is widely understood in contemporary culture, an acceptance of how all cultural forms convey an exclusionary ideological stance of some sort, with reflexive rigour or ethical earnestness providing no immunity to a potential perception of bias. Noting that hatred is endemic to the hipster, Mark Greif, author of What Was The Hipster?: A Sociological Investigation, claims that the hipster trope rouses so much animosity in people because it 'calls everyone's bluff', at once evoking and masking the limitations of one's own tastes. $^{67}$ In the words of Pierre Bourdieu, 'since taste is the basis of all that one has', when tastes have to be justified 'they are asserted purely negatively, by the refusal of other tastes. In matters of taste, more than anywhere else, all determination is negation'. ${ }^{68}$

The difficulty of speaking about the hipster as if one is outside the hierarchical system of taste was apparent after a 2009 symposium on the "end of the hipster" in New York spawned accusations that the staging of the symposium was itself a product of hipster musings. As Rob Horning, one of the speakers, later recounted about the event: 'It's impossible to obtain objective distance from hipsterism; if you are concerned enough about the phenomenon to analyze it and discuss it, you are already somewhere on the continuum of hipsterism and are in the process of trying to rid yourself of its "taint.", 69

For Slavoj Žižek, who reflected specifically on Horning's statement, what is remarkable about the hipster as a subcultural trope is that it is always presented as an objective rather than a subjective phenomenon. For this reason, he thinks that any analysis of the hipster must start from the perspective of the accusatory subject - the 'not me' who is simultaneously embedded 'in the taint of hipsterism and capable of uttering the utterance "hipster". ${ }^{70}$ Drawing on Jacques Lacan, Žižek defines the hipster as a type of 'double' who allows the accuser to maintain an image of their own individuality 'but only as the dislocated site of imagined and imaginary resistance'. ${ }^{71} \mathrm{He}$ states:

The utterance "hipster" finds its analogy in the sobbing flight of the debutante who arrives at the dance only to discover that another girl is wearing an identical dress. The debutante's double calls into question her own sense of self. In order to

\footnotetext{
${ }^{66}$ Rancière, 2009b, p. 45.

${ }^{67}$ Grief, 2010, p. 16.

${ }^{68}$ Bourdieu, 1984, p. 56.

${ }^{69}$ Horning, 2009: http://www.popmatters.com/post/the-death-of-the-hipster-panel/; 30 September, 2014.

70 Žižek, 2009, p. 3.

71 Žižek, 2009, p. 6.
} 
reconnect with her individualism she must flee from the sight of her double. But what would it mean if the debutante had planned the entire social disaster, including the existence of her own double and her ridiculous exit, in advance? The utterance "hipster" presents us with just such a scenario. ${ }^{72}$

Describing the hipster and its utterance as the 'symptom' in Lacan's writings, Žižek presents Lacan's diagram of the Borromean Knot, which consists of three overlapping rings representing the Real, the Imaginary and the Symbolic that Lacan used to illustrate how psychosis is the result of any one of these three interlocking modalities being severed. He continues:

The symptom is that ring that must come into existence when the knot itself is threatened. Hipster is that place where the real, the imaginary and the symbolic combine into one. The hipster, known only through the utterance "hipster", is, then, the overcoming of an individual as well as a cultural psychosis, through an act of individual and group projection ... ${ }^{73}$

Here Žižek defines the hipster less an externally located cultural identity than a neurotic expression made in response to a perceived threat to one's autonomous identity - a point of distinction from our stylised selves that serves to mask how hierarchies are central to identity-formation and to cultural life more generally. In this the hipster resembles Žižek's definition of ideology itself, which he describes as 'the paradox of a being which can reproduce itself only in so far as it is misrecognized and overlooked. The moment we see it "as it really is", this being dissolves itself into nothingness or, more precisely, it changes into another kind of reality. ${ }^{74}$

In 2014 the word "normcore" was suggested by the trend forecasting agency K-Hole as an anti-cool mode of fashion of the moment, opposed to the phenomenon of the hipster. Normcore has since become synonymous with the clothing brand Gap whose tagline for their 2014 Autumn campaign was "dress normal", publicised in a series of ads by the film director David Fincher that pronounce: 'Let your actions speak louder than your clothes.' While this is just another strategic fashion manoeuvre, it speaks of a tendency today towards minimising aesthetic irony, as if trying to minimise excessive emphasis on form in order to embrace substance. For K-Hole, normcore is about 'adaptability not exclusivity ${ }^{75}$ and signals a move from the hipster's 'coolness that relies on difference to a post-authenticity coolness that opts into sameness'. ${ }^{76}$ Ultimately though, normcore's reversal of hipster individualism can be seen as itself a hipster strategy only taking a more conceptual form, remaining dependent on the recognition of its "wink" in order for its hipster subversion to be seen.

${ }^{72}$ Žižek, 2009, p. 6.

${ }^{73}$ Žižek, 2009, p. 9.

74 Žižek, 1989, p. 28.

${ }^{75}$ K-Hole, 2013, p. 24.

${ }^{76}$ K-Hole, 2013, p. 26. 
As a connoisseurial and artistic trope, the hipster might refer to the point at which niche identity-forms become regarded as generic, or when inventive individual taste becomes shared taste; however, it also serves as a defence against social and individual anxieties about taste and distinctiveness in an age of inclusivity and rapid re-distributions of value. Caught up in the power of taste and the power of its denunciation the hipster presents as a kind of spectre in contemporary culture, a figure of hate through which we can identify the politics of taste in neoliberalist culture while distancing ourselves from our place in its system.

Wes Hill is a lecturer of art theory and visual culture at Southern Cross University, New South Wales. His most recent publication is How Folklore Shaped Modern Art (Routledge, 2016) and his critical writing appears regularly in journals and magazines such as Artforum, Frieze, Eyeline and Art Monthly Australia.

\section{Bibliography}

Arjun Appadurai, 1990: Arun Appadurai, 'Disjuncture and Difference in the Global Cultural Economy', Theory, Culture \& Society, 7, no. 2, 1990, pp. 295-310.

Baker, 2004: George Baker, Introduction to 'Antagonism and Relational Aesthetics' by Claire Bishop, October, 110, Fall, 2004, pp. 49-50.

Bishop, 2004: Claire Bishop, 'Antagonism and Relational Aesthetics', October, 110, Fall 2004, pp. 51-79.

Bishop, 2006: Claire Bishop, 'The Social Turn: Collaboration and Its Discontents', Artforum, February, 2006, pp. 179-185.

Bishop, 2012: Claire Bishop, Artificial Hells: Participatory Art and the Politics of Spectatorship, New York: Verso, 2012.

Bourdieu, 1984: Pierre Bourdieu, Distinction: A Social Critique of the Judgment of Taste, trans. Richard Nice, Cambridge: Harvard University Press, 1984.

Bourriaud, 2002: Nicholas Bourriaud, Relational Aesthetics, trans. Simon Pleasance et. al., Paris: Les Presses du Reel, 2002.

Broyard, 1948: Anatole Broyard, 'Portrait of a Hipster', Partisan Review, 15, no. 6, 1948, pp. 721-26. 
Calloway, 1976: Cab Calloway, 'The Hepster's Dictionary: Language of Jive', in John Shearer (ed.), Of Minnie the Moocher \& Me, New York: Thomas Crowell, 1976.

Chayka, 2011: Kyle Chayka, 'WTF is Relational Aesthetics', Hyperallergic, February 8, 2011, http://hyperallergic.com/18426/wtf-is-relational-aesthetics/; accessed September $21,2014$.

Crow, 2009: Thomas Crow, 'Village Green Preservation Society,' in Ann Gallagher (ed.), Damien Hirst, London: Arken, 2009.

Debord, 1994: Guy Debord, The Society of the Spectacle, New York: Zone Books, 1994.

Florida, 2002: Richard Florida, The Rise of the Creative Class, New York: Basic Books, 2002.

Florida, 2014: Richard Florida. 'More Losers than Winners in America's New Economic Geography', CityLab, January 30, 2013, http://www.citylab.com/work/2013/01/morelosers-winners-americas-new-economic-geography/4465/; accessed 19 September, 2014.

Foster, 1993: Hal Foster, 'Postmodernism in Parallax', October, 63, Winter, 1993, pp. 320 .

Foster, 2003: Hal Foster, 'Arty Party', London Review of Books, December 4, 2003, pp. 21-22.

Foucault, 2008: Michel Foucault, The Birth of Biopolitics, New York: Palgrave Macmillan, 2008.

Frank, 1997: Thomas Frank, The Conquest of Cool, Chicago: University of Chicago Press, 1997.

Ginsberg, 1959: Allen Ginsberg, Howl and other poems, San Francisco: City Lights Books, 1959.

Gladwell, 1997: Malcom Gladwell, 'The Coolhunt', The New Yorker, March 17, 1997, http://www.newyorker.com/magazine/1997/03/17/the-coolhunt; accessed 2 January, 2016.

Greif, 2010: Mark Greif, What was the Hipster? A Sociological Investigation, New York: n+1 Foundation, 2010. 
Harvey, 2005: David Harvey, A Brief History of Neoliberalism, New York: Oxford University Press, 2005.

Hebdige, 1979: Dick Hebdige, Subculture: The meaning of Style, New York: Methuen \& Co, 1979.

Horning, 2009: Rob Horning, 'The Death of the Hipster', PopMatters, 13 April, 2009, http://www.popmatters.com/post/the-death-of-the-hipster-panel/; accessed September 30, 2014.

Huang, 2014: Shan Huang, 'Independence at Large: Contemporary China's Alternative Music Scenes and the Cultural Practices of Post-Socialist Urban Youth', Masters thesis, University of South Carolina, 2014.

Jones, 2010: Ronald Jones, ‘Analyse This,' Frieze, 133, 2010, pp. 54-58.

K-Hole, 2014: K-Hole, 'Youth Mode: A Report on Freedom', K-Hole, October, 2013.

Kerouac, 1976: Jack Kerouac, On the Road, New York: Penguin Books, 1976.

Kester, 2009: Grant Kester, 'Questionnaire on the Contemporary,' October, 130, Fall, 2009, pp. 7-9.

Kester, 2011: Grant Kester, The One and the Many: Contemporary Collaborative Art in a Global Context, North Carolina: Duke University Press, 2011.

Kurutz, 2013: Steven Kurutz. 'Caught in the Hipster Trap', New York Times, September 14, 2013, http://www.nytimes.com/2013/09/15/opinion/sunday/caught-in-the-hipstertrap.html?_r=0; accessed 1 October, 2014.

Lacayo, 1994: Richard Lacayo, 'If Everyone Is Hip ... Is Anyone Hip?', Time, 144, no. 6, August 8, 1994, pp. 48-56.

Latour, 2014: Bruno Latour, 'Why Has Critique Run Out of Steam? From Matters of Fact to Matters of Concern', Critical Inquiry, 30, no. 2, 2004, pp. 225-248.

Mailer, 1957: Norman Mailer, 'The White Negro: Superficial Reflections on the Hipster', Dissent, 4, no. 3, 1957, pp. 276-93. 
Millard, 2001: Rosie Millard, The Tastemakers: UK Art Now, London; Thames and Hudson, 2001.

Persad, 2014: Michelle Persad, 'The 13 Most Hipster Items of Clothing', Huffington Post, July 16, 2014, http://www.huffingtonpost.com.au/entry/hipsterclothing_n 5589392.html?section=australia; accessed 2 February, 2016.

Polsky, 1967: Ned Polsky, Hustlers, Beats, and Others, Chicago: Aldine Publishing Company, 1967.

Rancière, 2009a: Jacques Rancière, The Emancipated Spectator, trans. Gregory Elliott, London and New York: Verso, 2009.

Rancière, 2009b: Jacques Rancière, Aesthetics and Its Discontents, trans. Steven Cochran, Cambridge: Polity Press, 2009.

Read, 2009: Jason Read, 'A Genealogy of Homo-Economicus: Neoliberalism and the Production of Subjectivity,' Foucault Studies, no. 6, 2009, pp. 25-36.

Saltz, 2011: Jerry Saltz, 'The Long Slide: Museums as Playgrounds', New York Magazine, December 4, 2011, http://nymag.com/arts/cultureawards/2011/museums-asplaygrounds/; accessed 10 September, 2014.

Stallabrass, 1999: Julian Stallabrass, High Art Lite: British Art in the 1990s, London \& New York: Verso, 1999.

Žižek, 1989: Slavoj Žižek, The Sublime Object of Ideology, London: Verso, 1989.

Žižek, 2009: Slavoj Žižek, 'L'etat d'hipster', Rhinocerotique, trans. Henry Brulard, September, 2009, pp. 3-10. 